\title{
Improving efficiency of decision making units through BSC-DEA technique
}

\author{
Amir Reza Khaki ${ }^{a^{*}}$, Seyed Esmaeel Najafi ${ }^{\mathrm{b}}$ and Sadra Rashidi ${ }^{\mathrm{a}}$
}

${ }^{a}$ Department of Industrial Engineering, Islamic Azad University, Ilam Branch, Ilam, Iran ${ }^{b}$ Education chair, Society of Reliability Engineering-Ottawa, Canada, Visiting Professor

\begin{tabular}{ll}
\hline A R T I C L E I N F O & A B S T R A C T \\
\cline { 3 - 3 } $\begin{array}{ll}\text { Article history: } \\
\text { Received July 2, 2011 }\end{array}$ & $\begin{array}{l}\text { Performance evaluation is one of the most important techniques to prioritize different decision } \\
\text { Received in Revised form }\end{array}$ making units. Data envelopment analysis (DEA), as a non-parametric method, plays an \\
August, 28, 2011 & important role for measuring relative efficiency. Balanced score card, on the other hand, is \\
Accepted 28 August 2011 & another method to evaluate a business plan based on non-financial perspectives. The integrated \\
Available online & BSC-DEA takes advantage of the advantages of both methods' features. In this paper, we \\
30 August 2011 & propose a BSC-DEA method to rank different decision making units. We consider different \\
\hline Keywords: & financial criteria such as profit-margin, return on assets along with non-financial criteria such as \\
Efficiency & customer satisfaction, advanced services, employee skills to compare the performance of \\
Decision making groups & different banks. The results are analyzed and discussed, which could be used for making better \\
Data envelopment analysis & decisions.
\end{tabular}

\section{Introduction}

Measuring the relative efficiency of any financial or non-financial firms has become an interesting issue among many interested researchers. It normally focuses on various components of an organization plans, processes as well as human factors by sufficient performance evaluation system for development and stability in today's competition field (Littler et al., 2000). The results of performance evaluation help us study deviation from objectives and targets. There are various reasons for measuring the relative efficiency in banking sector such as:

1. It can be used to control branches, which must be surveyed based on the status of utilizing appropriate standards,

2. The performance of managers of the bank units ought to be rewarded by a proper punishment and encouragement system for creating responsibility feeling.

3. Performance measurement helps us set up some standards.

\footnotetext{
* Corresponding author. Tel: +989181413107

E-mail addresses: amirk28@yahoo.com (A. R. Khaki) 
4. Performance measurement could create a safe competition among branches by evaluating different branches and determine their faults and powers.

During the past two decades, there have been tremendous change on performance measurement. The main objective of modern evaluation is mostly on growth, development and improvement of assessed capacity. The new measuring systems are focused on strategic implementation to detect the critical success factors (CSF) for the present and the future strategic planning. If the CSF factors are improved, the business units will implement and execute their strategies. These systems use internal factors, which lead to be changed to external ones. Instead of monitoring duty performances, the way of implementation process based on environmental conditions and the way of implementation of strategy is concerned. BSC is a new performance measurement system which surveys the organization on four perspectives of learning of personal, internal processes, customer and finance. Measuring output efficiency has constantly been one of the significant discussions in management. The main objective of each organization is efficient productivity of existing sources. Applying advanced techniques and determining opportunities and potential and practical limits need sufficient knowledge on the present circumstances of the organization, which leads us to implement DEA methods.

In this paper, we present an integrated balanced score card (BSC) \& DEA model, in which the inputs and the outputs are selected based on BSC and they are measured by DEA model. Therefore, by integrating BCS model, in addition on studying on financial factors as past perspective, we utilize three future perspectives indices for the growth and the importance of DMU capacities to take effective steps. This paper is organized as follows. In section two and three, we explain both BSC and DEA approaches and their integration are developed in section 4. In the section 5, two methods of integrated BSE-DEA are explained and finally the results of implementation of the mentioned model in 20 branches of a bank located in Iran are explained and analyzed.

\section{Introduction of data envelopment analysis}

Charnes, Cooper and Banker are the first people who introduced DEA method (Charnes \& Cooper, 1978; Banker et al. 1985). DEA measures the efficiency of decision-making departments of organization based on different inputs and outputs. During two decades, there have been significant attempts on developing various DEA methods (Andersen \& Petersen, 1993). Lin and Hong (2006) applied DEA for measuring the relative efficiency of major international airports. In their DEA method, they used five inputs of the number of employees, the landing band length, the parking size, the airlines stations and the terminal spaces. Using three outputs of the number of passengers, the cargo and number of trips, they implemented DEA and extracted the ranking of various airlines in four groups. Tseng et al. (2008) studied the performance of major international airports in the world. Roghanian and Foroghi (2010) used a robust DEA to measure the relative efficiency of Iranian regional airlines.

Giokas (2008) implemented DEA for measuring the relative efficiencies of major Greek banks by considering nine inputs and eight output factors. Bergendahl and Lindblom (2008) used DEA method for a bank located in Sweden. In their empirical analysis, they chose 88 independent investment banks from year 1997 to year 2001 and evaluated their relative efficiencies. Ramanathan (2007) in an assignment used DEA to measure the relative efficiencies of various Arab countries located in Persian Gulf. In his study, the information of 55 major banks of Bahrain, Kuwait, Oman, Qatar, Saudi Arabia and Emirates between year 2000 and 2004 were utilized. The report indicated that 15 banks were identified as efficient units and the relative efficiencies of other banks were compared using these 15 banks. Adler and Golany (2001) implemented DEA for western European airlines and divided the airlines into two efficient and inefficient units. Sadjadi and Omrani (2008, 2010) proposed a robust form of DEA method to reduce the effects of uncertainty in input and output data. 
One of the main concerns on DEA is to determine the most productive scale size (MPSS). The concept of MPSS was first studied by Banker et al. (1985). They defined the MPSS as producing size, which has the most production average compared each produces unit that has the same false combination of input and output for DMU. The performance evaluation must be continually executed in an organization to achieve continues improvement. During the process of BSC some important factors, which influence the efficiency of an organization such as inflation, the condition of competitors and the strategy of organization are determined. One important issue, which must be always considered is the effect of each parameter on MPSS.

\section{Introduction of balanced scorecard model}

Kaplan and Norton (1992) are the first who introduced the idea of BSC as a new method for measuring the performance of a system. Norton and Kaplan emphasized on the importance of strategy execution more than the strategy itself (Kaplan \& Norton, 1996, 2001). The idea of BSC is to look into non-financial items affecting the efficiency of a business unit. In the past, financial factors were only considered for performance evaluation. However, BSC explains the indices toward four outlooks of growth and learning, internal processes, customer and finance and intends to balance financial goals as a result of past performance (past view indices) and three other indices (future view indices) (Abran \& Buglione, 2003). Fig 1 shows the details of the financial and non-financial parameters.

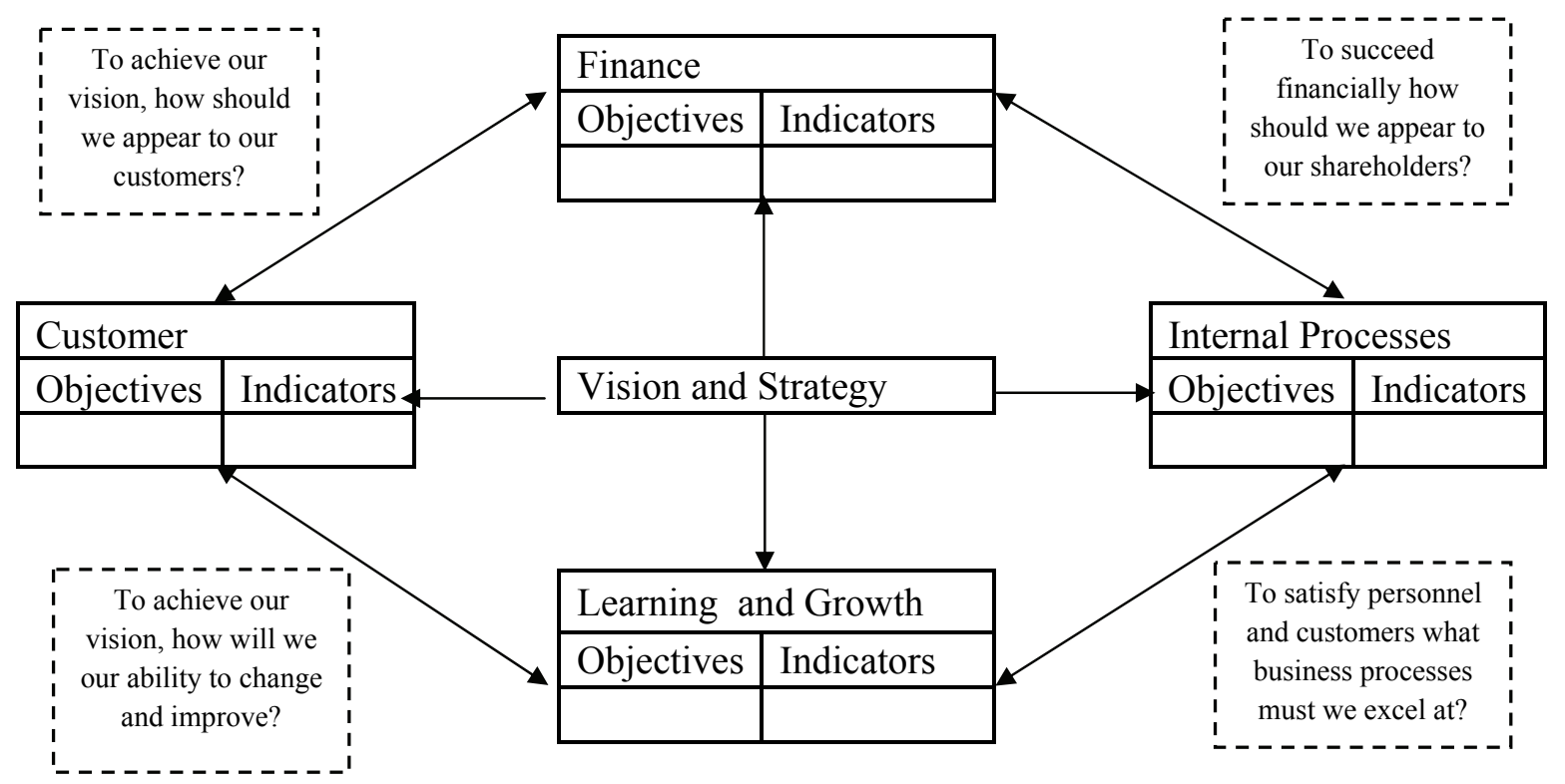

Fig. 1. Four perspectives of balanced scorecard

Kaplan and Norton also explained that there is a cause and effect relationship among goals and indices of these four perspectives. A proper scorecard creates cause and effect relationship among the current activities and the success of the organization in a long time for a prolonged period. Since the development of organization is based on its intangible assets, the balanced scorecard is an important tool for their control and management. Note that to reach the financial outcomes (in financial perspective), the customers must be esteemed according to customer's perspective, which is attained only by matching the operational processes with the customers' requirements based on internal processes perspective. 
We normally achieve operational elevation and create valuable processes solely by creating suitable work environment for the personnel and encouraging them for creativity, learning and development in the organization (McPhail et al., 2008; Greatbanks \& Tapp, 2007; Davis \& Albright, 2004; Huang, 2009; Hung-Yi et al. 2009).

The idea of using integrated BSC-DEA was used for different organizations in the past. Banker et al. (2004) implemented integrated BSC-DEA method for over 50 local exchange carriers operating in the United States of America, based on operating data collected from year 1993 to year 1997. They considered return on asset(ROA) as a financial performance indicator and three non-financial performance indicators including number of access lines per employee, percentage of digital access lines and percentage of business access lines, for the US telecommunications industry. They reported that management team must trade off contemporaneous ROA when increasing the percentage of business access lines.

Chen (2008) performed an investigation on investment risk for performance evaluation of different banks located in Taiwan. He evaluated the management risk based on five perspectives of BSC including financial, customer, internal processes, growth and learning and risk and then evaluated the output data by using DEA.

Harel et al. $(2006,2008)$ in two different works used BSC-DEA model for evaluating R \& D projects. In the first work, they developed a methodology for R\&D portfolio analysis in which effectiveness, efficiency, and balance considerations were integrated. The methodology was based on relative evaluation of entities, which includes projects or portfolios. Harel et al. (2008) added uncertainty perspective to traditional perspectives of BSC and implemented their proposed BSC-DEA model to for ranking 50 projects.

Valderrama et al. (2008) integrated BSC-DEA model for evaluating R \& D projects. In this model, innovation perspective considered as fifth perspective and five separate models were defined.

Asosheh et al. (2010) proposed integrated BSC-DEA model for evaluating information technology (IT) projects where uncertainty perspective was added to BSC model as an additional perspective. The uncertainty perspective includes various measures such as processes risks, human resource risks and technology risks.

\section{An Integrated BSC-DEA model}

As we explained earlier, one of the major reasons for the success of any organization is the proper implementation of the strategy which could be achieved using BSC-DEA. One of the advantages of BSC is compiling indices; hence, using BSC for compiling indices is created according to the strategy of organizations and can increase its capability along with DEA. Identifying various performance evaluation models and determining the accurate and appropriate usage of the methods in the organization is an important issue in performance evaluation discussion, since inaccurate selection of a method could lead to an unpleasant situation and vice versa.

\subsection{Case study}

In this section, we present an empirical study for the implementation of our propose BSC-DEA. As we explained earlier, the performance of banking sector is mostly measured based on non-financial figures. Today, basic financial data such as return on assets cannot explain the whole picture of business units, there are other issues, which are important, and we must take into account. The proposed study of this case study implements BSC-DEA on 20 branches of one of Iranian banks. The study uses various financial and non-financial items for its assessment summarized in Table 1. 
Table 1

The summary of different financial and non-financial factors used for the proposed BSC-DEA

\begin{tabular}{|c|c|c|c|c|c|}
\hline & & & Inputs & & Outputs \\
\hline \multirow[b]{2}{*}{1} & \multirow{2}{*}{$\begin{array}{l}\text { Financial } \\
\text { Perspective }\end{array}$} & I1 & Unpaid loans & 01 & Profit margin \\
\hline & & I2 & Cost to revenue ratio & $\begin{array}{l}02 \\
03\end{array}$ & $\begin{array}{l}\text { Return on equity } \\
\text { Asset growth rate }\end{array}$ \\
\hline 2 & $\begin{array}{l}\text { Customer } \\
\text { Perspective }\end{array}$ & I1 & Competitive pricing strategy & $\begin{array}{l}\mathrm{o} 1 \\
\mathrm{o} 2 \\
\mathrm{o} 3\end{array}$ & $\begin{array}{l}\text { New customers' rate } \\
\text { Fast and high quality service } \\
\text { Customer satisfaction }\end{array}$ \\
\hline 3 & $\begin{array}{l}\text { Internal } \\
\text { Perspective }\end{array}$ & $\begin{array}{l}\mathrm{I} 1 \\
\mathrm{I} 2\end{array}$ & $\begin{array}{l}\text { Online services } \\
\text { Fast and reliable services }\end{array}$ & $\begin{array}{l}\text { o1 } \\
\text { o2 }\end{array}$ & $\begin{array}{l}\text { Electronic services } \\
\text { Advanced services }\end{array}$ \\
\hline 4 & $\begin{array}{l}\text { Growth and } \\
\text { Learning }\end{array}$ & $\begin{array}{l}\mathrm{I} 1 \\
\mathrm{I} 2\end{array}$ & $\begin{array}{l}\text { Increased employee's specialties } \\
\text { Increase motivational expenses }\end{array}$ & o1 & Advances on employees' skills \\
\hline
\end{tabular}

We have implemented DEA method to measure the relative efficiencies of all 20 units and Table 2 shows the efficient units in terms of all four perspectives.

Table 2

The summary of efficient units based on each BSC perspective using DEA method

\begin{tabular}{|c|c|c|c|c|c|c|c|c|c|c|c|c|c|c|c|c|c|c|c|c|}
\hline & \multicolumn{20}{|c|}{ Efficient units } \\
\hline Perspective & 1 & 2 & 3 & 4 & 5 & 6 & 7 & 8 & 9 & 10 & 11 & 12 & 13 & 14 & 15 & 16 & 17 & 18 & 19 & 20 \\
\hline Financial & 1 & & 1 & & 1 & & 1 & & 1 & & 1 & & 1 & & 1 & 1 & & & & 1 \\
\hline Customer & & 1 & & & & & & 1 & & 1 & & & & 1 & & & & 1 & 1 & \\
\hline Internal & & & & 1 & & & & & & & & 1 & & & & & 1 & & & \\
\hline Growth \& Learning & & & & & & 1 & & & & & & & & & & & & & & \\
\hline
\end{tabular}

As we can observe from Table 2, the efficient units are located in four different levels and they need to upgrade to a new levels step by step. In the financial level, we could use other efficient units to build efficient benchmark for inefficient ones and the results are summarized in Table 3.

Table 3

The summary of building efficient units based on other decision making units (DMUs)

\begin{tabular}{|c|c|c|c|c|c|c|c|c|c|c|}
\hline DMU & 1 & 2 & 3 & 4 & 5 & 6 & 7 & 8 & 9 & 10 \\
\hline Efficiency & 1 & 0.8 & 1 & 0.63 & 1 & 0.38 & 1 & 0.94 & 1 & 0.94 \\
\hline Benchmark & - & $\begin{array}{l}1(0.963) \\
11(0.36)\end{array}$ & - & $\begin{array}{l}1(0.389) \\
11(0.611)\end{array}$ & - & $\begin{array}{l}1(0.575) \\
11(0.425) \\
1(0.431)\end{array}$ & - & $\begin{array}{l}11(0.486), \\
13(0.64)\end{array}$ & - & $\begin{array}{l}1(0.389) \\
11(0.579)\end{array}$ \\
\hline DMU & 11 & 12 & 13 & 14 & 15 & 16 & 17 & 18 & 19 & 20 \\
\hline Efficiency & 1 & 0.57 & 1 & 0.89 & 1 & 1 & 0.59 & 0.94 & 0.63 & 1 \\
\hline Benchmark & - & $\begin{array}{l}1(0.431) \\
11(0.473)\end{array}$ & - & $16(11)$ & - & - & $\begin{array}{l}7(0.287), \\
13(0.493), 15(0.22)\end{array}$ & $\begin{array}{l}\text { 13(044), } \\
19(0.71) \\
20(0.064)\end{array}$ & $\begin{array}{l}1(0.161), 9(0.076), \\
13(0.453), 20(0.311)\end{array}$ & - \\
\hline
\end{tabular}

Similarly, we could build efficient units for inefficient units in the second level and the results are summarized in Table 4.

Table 4

The summary of building efficient units based on other decision making units (DMUs)

\begin{tabular}{cccccc}
\hline DMU & Efficiency & Benchmark & DMU & Efficiency & Benchmark \\
\hline 2 & 1 & ----- & 12 & 0.928 & $10(0.444), 19(0.556)$ \\
4 & 0.764 & $2(0.157), 10(0.761), 10(0.082)$ & 14 & 1 & - \\
6 & 0.482 & $10(1)$ & 17 & 0.8 & $10(0.36), 18(0.3), 19(0.338)$ \\
8 & 1 & ----- & 18 & 1 & - \\
10 & 1 & ---- & 19 & 1 & \\
\hline
\end{tabular}


Finally, we can build the benchmark units for the third level of BSC structure and the results are summarized in Table 5.

Table 5

The summary of building efficient units based on other decision making units (DMUs)

\begin{tabular}{ccc}
\hline DMU & Efficiency & Benchmark \\
\hline 4 & 1 & - \\
6 & 0.7 & $4(0.3), 12(0.7)$ \\
12 & 1 & - \\
17 & 1 & - \\
\hline
\end{tabular}

It is interesting to have a whole picture on benchmark units for three levels and we have gathered all benchmark ones in Table 6 as follows,

Table 6

The summary of benchmark units

\begin{tabular}{|c|c|c|c|c|c|c|c|c|c|c|c|c|c|c|c|c|c|c|c|c|}
\hline DMU & 1 & 2 & 3 & 4 & 5 & 6 & 7 & 8 & 9 & 10 & 11 & 12 & 13 & 14 & 15 & 16 & 17 & 18 & 19 & 20 \\
\hline \multirow{3}{*}{ Customer } & & & & & & 1 & & & 1 & 1 & & 1 & & 1 & 1 & & & 1 & & \\
\hline & 1 & 1 & & & 1 & & 1 & 1 & & & 1 & & & & & 1 & 1 & & 1 & 1 \\
\hline & & & 1 & 1 & & & & & & & & & 1 & & & & & & & \\
\hline Internal & 1 & 1 & & & & 1 & & & 1 & & & 1 & & & & & 1 & & & \\
\hline \multirow{4}{*}{ processes } & & & 1 & 1 & 1 & & 1 & & & 1 & & & & & & & & & & 1 \\
\hline & & & & & & & & 1 & & & & & & & 1 & 1 & & & 1 & \\
\hline & & & & & & & & & & & 1 & & & 1 & & & & 1 & & \\
\hline & & 1 & & & & & & & & 1 & 1 & & & & 1 & & 1 & 1 & & \\
\hline \multirow{4}{*}{$\begin{array}{l}\text { Learning } \\
\text { and } \\
\text { Growth }\end{array}$} & 1 & & & 1 & & & & & & & & 1 & & & & & & & & \\
\hline & & & 1 & & 1 & 1 & 1 & & 1 & & & & & & & & & & & 1 \\
\hline & & & & & & & & 1 & & & & & & & & 1 & & & 1 & \\
\hline & & & & & & & & & & & & & 1 & 1 & & & & & & \\
\hline
\end{tabular}

\section{Conclusion}

In this paper, we have presented a BSC-DEA method to rank different decision making units. We have considered various financial criteria such as profit-margin, return on assets along with nonfinancial criteria such as customer satisfaction, advanced services, employee skills to compare the performance of 20 units of banks through an integrated BSC-DEA method. The proposed model of this paper used four levels of learning and growth, internal, customer and financial perspectives for measuring the strength and weakness of 20 different branches of the bank. We have determined the efficient units in terms of four perspectives and presented benchmark scale to convert inefficient units into efficient ones.

\section{Acknowledgment}

The authors would like to thank the anonymous referees for their constructive comments on earlier version of this work. The present work was financially supported by Islamic Azad University of Ilam and the authors would like to express their gratitude for their support.

\section{References}

Abran A., \& Buglione L. (2003). A multidimensional performance model for consolidating Balanced 
Scorecards, Advances in Engineering Software, 34, 339-349.

Adler N., \& Golany B. (2002). Evaluation of deregulated airline network using data envelopment analysis combined with an application to Western Europe, European Journal of Operational Research, 132, 260-273.

Andersen P., \& Petersen N. C. (1993). A procedure for ranking efficient units in data envelopment analysis, Management Science, 39, 1261-1264.

Asosheh A., Nalchigar S., \& Jamporazmey M. (2010). Information technology project evaluation: An integrated data envelopment analysis and balanced scorecard approach, Expert Systems with Applications, 37, 5931-5938.

Banker R.D, Charnes A., \& Cooper W.W. (1984). Some models for estimating technical and scale inefficiencies in DEA, Management Science, 32,1078-92.

Banker R.D., Chang H., Janakiraman S.N., \& Constantine Konstans. (2004). A balanced scorecard analysis of performance metrics, European Journal of Operational Research, 154, 423-436.

Bergendahl G., \& Lindblom T. (2008). Evaluating the performance of Swedish savings banks according to service efficiency, European Journal of Operational Research ,185, 1663-1673.

Charnes A., Cooper W. W., \& Rhodes E. (1978). Measuring the efficiency of decision making units, European Journal of Operational Research, 6, 429-44.

Chen T., Chen C., \& Peng S. (2008). Firm operation performance analysis using data envelopment analysis and balanced scorecard.A case study of a credit cooperative bank, International Journal of Productivity and Performance Management, 57, 523-539.

Dimitris I. G., (2008). Assessing the efficiency in operations of a large Greek bank branch network: adopting different economic behaviors, Economic Modeling, 25, 559-574.

Davis S., \& Albright T. (2004). An investigation of the effect of Balanced Scorecard implementation on financial performance, Management Accounting Research, 15, 135-153.

Eilat H., Golany B., \& Shtub A. (2006). Constructing and evaluating balanced portfolios of R\&D projects with interactions: A DEA based methodology, European Journal of Operational Research, 172, 1018-1039.

Eilat H., Golany B., \& Shtub A. (2008). R\&D project evaluation: An integrated DEA and balanced scorecard approach, The International Journal of Management Science, 36, 895 - 912.

García-Valderrama T., Mulero-Mendigorri E., \& Revuelta-Bordoy D. (2009). Relating the perspectives of the balanced scorecard for R\&D by means of DEA, European Journal of Operational Research, 196, 1177-1189.

Greatbanks R., \& Tapp D. (2007). The impact of balanced scorecards in a public sector environment: empirical evidence from Dunedin city council, New Zealand, International Journal of Operations \& Production Management, 27, 846-873.

Huang H.C. (2009). Designing a knowledge-based system for strategic planning: A balanced scorecard perspective, Expert Systems with Applications, 36, 209-218.

Hung-Yi .W, Tzeng G., \& Chen Y. (2009). A fuzzy MCDM approach for evaluating banking performance based on Balanced Scorecard, Expert Systems with Applications, 36, 10135-10147.

Hwang, K.C. (2008). Efficency decomposition in two-stage data envelopment analysis:an application to non-life insurance companies in Taiwan, European Journal of Operational Research, 185, 418-429.

Kaplan, R. S. \& Norton, D. P. (1992). The balanced scorecard - measures that drive performance, Harvard Business Review, 70(1), 71-79.

Kaplan, R.S. \& Norton, D.P. (1996). The balanced scorecard: translating strategy into action, Harvard Business School Press, Boston, MA.

Kaplan, R. S. \& Norton, D. P. (2001). The strategy-focused organization: how balanced scorecard companies thrive in the new business environment, Harvard Business School Publishing Corporation.

Littler J., Aisthorpe P., Hudson R., \& Keasey K. (2000). A new approach to linking strategy formulation and strategy implementation: an example from the UK banking sector, International 
Journal of Information Management, 20, 411-428

McPhail R., Heringtonb C., \& Guilding C. (2008). Human resource managers' perceptions of the applications and merit of the balanced scorecard in hotels, International Journal of Hospitality Management, 27, 623-631.

Ramanathan R. (2007). Performance of banks in countries of the Gulf Cooperation Council, International Journal of Productivity and Performance Management, 56, 137-154.

Roghanian, E. \& Foroghi, A. (2010). An empirical study of Iranian regional airports using robust data envelopment analysis, International Journal of Industrial Engineering Computations, 1, 6572.

Sadjadi, S. J. \& Omrani, E. (2008). Data envelopment analysis with uncertain data: An application for Iranian electricity distribution companies, Energy Policy, 36(11), 4247-4254.

Sadjadi, S. J. \& Omrani, E. (2010). A bootstrapped robust data envelopment analysis model for efficiency estimating of telecommunication companies in Iran, Telecommunications Policy, 34(4), 221-232. 